(ISSN - 2752-7018)

VOLUME 02 ISSUE 01 Pages: 57-62

SJIF IMPACT FACTOR (2021: 5. 376)

OCLC -1276789625 METADATA IF -7.569
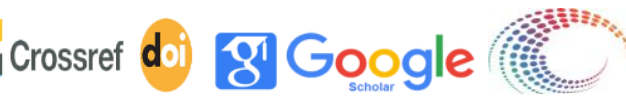

metapata indexing "5 WorldCat" fir MENDELEY

Publisher: Frontline Journals

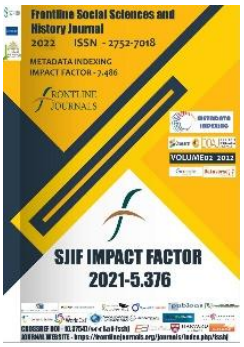

Journal Website: https://frontlinejournal s.org/journals/index.ph $\mathrm{p} /$ fsshj

Copyright: Original content from this work may be used under the terms of the creative commons attributes 4.0 licence.
Research Article

\section{RESEARCHES OF RUSSIAN ETHNOGRAPHERS ON THE WEDDING CEREMONIES OF THE OASIS OF BUKHARA}

Submission Date: January 11, 2022, Accepted Date: January 21, 2022,

Published Date: January 31, 2022

Crossref doi: https://doi.org/10.37547/social-fsshj-02-01-07

\section{Zilola Shamsieva}

Bukhara State University, Teacher Of The Department "History Of Bukhara", Uzbekistan

\title{
Abstract
}
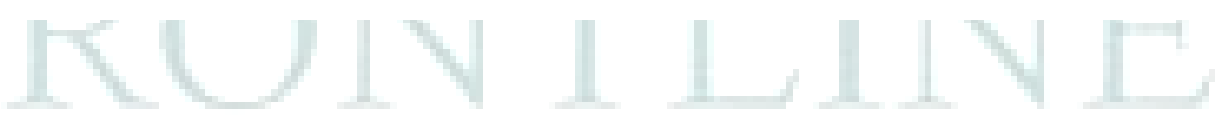

The article is devoted to the analysis of the traditions associated with the wedding ceremonies of Bukharian people and the role of these ceremonies in the life of the nation. Given article also provides information on comments of particular researchers on various traditions of the wedding ceremony held in Bukhara in the second half of 20th century.

\section{KeYwords}

Ethnography,wedding, ceremony, tradition, O.A. Sukhareva, N.A.Kislyakov, T.G.Emelyanenko], N.P.Lobacheva, rituals before and after the wedding. 
(ISSN - 2752-7018)

VOLUME 02 ISSUE 01 Pages: 57-62

SJIF IMPACT FACTOR (2021: 5. 376)

OCLC -1276789625 METADATA IF -7.569

\section{INTRODUCTION}

The wedding ceremony is a wonderful family holiday, which is always held as a symbol of joy, youth, beauty, good hopes for the future and noble dreams. Although it is in fact a time-tested, deeply thought-out, ationally celebrated ceremony, it has been constantly improved and enriched over time. Of course, not only certain ethnic groups, but even every village, district or province can have its own elements of a traditional wedding. Therefore, it can be said that wedding ceremonies embody the specific local characteristics of a particular ethnic group, and the study of the transformation processes of these ceremonies is one of the urgent problems that need to be studied in the science of ethnography.

Wedding is one of the most important events in the life of any person, regardless of nationality, gender, race, skin color, religion and ideology. In Bukhara, this process consists of many interrelated parts, and all of them are called weddings as a whole.

\section{THE MAIN FINDINGS AND RESULTS}

Nowadays, weddings, which are common among Uzbeks, are held in accordance with traditional customs, with the bride and groom volunteering on the advice of parents, close relatives and friends. In many places, traditional rituals such as "fatiha oshi", "sending presents to bride ", "kuda tanishu", "hayitlik", "girls' feast", "padar oshi" or "chimildiq yigdi" are held before the wedding whereas, rituals such as "bride greetings", "challar" or "groom call" and especially large and small weddings are held after the bride is brought to the home of the groom.

Many researchers have provided information about the traditional system of wedding ceremonies in Bukhara in their historical and ethnographic articles and pamphlets. In particular, about the wedding ceremonies held in the Zarafshan oasis in the XX century, we read 0.A. Sukhareva[1], N.A.Kislyakov[2], a number of scientific articles by T.G.Emelyanenko[3], N.P.Lobacheva[4] provide ethnographic analysis.

The various customs and rituals of the peoples living in and around Bukhara have been 
(ISSN - 2752-7018)

VOLUME 02 ISSUE 01 Pages: 57-62

SJIF IMPACT FACTOR (2021: 5 • 376)

OCLC -1276789625 METADATA IF -7.569

Publisher: Frontline Journals

scientifically studied and analyzed by several Russian researchers in the last century. Ethnographer O.A.Sukhareva, who made a significant contribution to Central Asian ethnography with her valuable research, studied the lifestyles, customs, clothing styles and many other aspects of both small and large ethnoses. In her major research, she focused on women's ceremonies and wrote about weddings and wedding ceremonies in the village of Shahristan, Samarkand region. The scholar also gives detailed information about the fact that the wedding ceremony takes place in the bride's house, the bride's mother prepares a sarpo for the groom, chimildiq, roybinon ceremonies. Although many aspects of women's ceremonies in the oasis are similar to those in the Bukhara oasis, we can also witness some distinctive features.

In addition, N.A.Kislyakov, a Russian researcher, provides valuable information about several ceremonies of the peoples of Central Asia. According to the scientist, the wedding ceremony consists of many rituals and separate ceremonies in the form of small events, and the knowledge gained as a result of studying these processes provides a lot of knowledge about the emergence and development of the family in society [2].

In his research, A.N. Kislyakov describes the wedding ceremonies of Kazakhs, Kyrgyz, Karakalpaks, Turkmen and Uzbeks, and says that the analysis of Uzbek weddings is complicated for various reasons. The reason for its complexity is that the ceremonies consist of many parts, and the Uzbek peoples themselves are divided into several parts (nomadic, seminomadic, relocated).

A.N. Kislyakov has been covering Uzbek weddings since the bridegroom came from the bridegroom's house to the bride's house as a bridesmaid. It is followed by counseling,a blessing wedding, an agreed (usually within a month) wedding. [2].

The research of contemporary ethnographer T.G. Emelyanenko provides some information about the peculiarities of wedding ceremonies with the participation of women in the Bukhara oasis, the similarities and differences in the traditions of the Tajik, Uzbek and Iranian peoples. In particular, the article "Sovremennaya svadba $\mathrm{v}$ 
(ISSN - 2752-7018)

VOLUME 02 ISSUE 01 Pages: 57-62

SJIF IMPACT FACTOR (2021: 5 • 376)

OCLC -1276789625 METADATA IF -7.569

Karakule: traditsii i innovatsii" analyzes the ethnographic analysis of the traditional wedding ceremony in Karakul district of Bukhara region and describes the similarities and differences of the rituals with the city of Bukhara and other districts. In particular, the scholar noted that the rituals performed by the people of Karakul came mainly from ancient Tajiks and Iranians, and now the people of the region call themselves Uzbeks [5]. In general, residents of the Karakol region positively perceive marriage between one village or a neighboring village. The people of Bukhara and Karakul consider each other to be people of a completely different world due to different traditions and worldviews. Marriage between relatives is very common. Such marriages were common among Tajiks, sedentary Uzbeks, and Turkmen. Occasionally there are cases of abduction and marriage (if there is parental opposition).

There are also cases of young marriages. The custom of "Qudo bini" (seeing the parents of the groom ) does not exist in Bukhararegion. The bride and groom are required to enter the bathroom on the morning of the wedding. This information was also pointed out by Russian ethnographer O.A.Sukhareva who noted in that in Bukhara, before the wedding ceremony, the bride was solemnly bathed, and this custom was popularly known as "hambombaron" (bathing). Older women in Bukhara reported that this practice was particularly prevalent among the Persians and the wealthy sections of the indigenous population. The ceremony of Qoshchinon (bride's eyebrow plucking on the eve of the wedding) was also held on the same day. There are reports that the hinobandon ceremony, which belongs to Tajiks, was held by locals before and is not being held now.

N.P.Lobacheva is also one of the enographers who deeply analyzed the weddings of the peoples of Uzbekistan. In her articles "On the formation of modern wedding ceremonies of the peoples of Uzbekistan", "Wedding ceremonies as a historical and ethnographic source" (on the example of Khorezm Uzbeks), "What is a wedding ceremony?" she gives an overview of the wedding ceremonies held in the Uzbek SSR in the mid-20th century, as well as the Samarkand the rituals of which are approximately similar to Bukhara such as,padaroshi, nonshikanon and other ceremonies. . [6]. 
(ISSN - 2752-7018)

VOLUME 02 ISSUE 01 Pages: 57-62

SJIF IMPACT FACTOR (2021: 5. 376)

OCLC -1276789625 METADATA IF -7.569

Publisher: Frontline Journals

\section{ConcLusion}

Today, it is expedient to make an in-depth analysis of all the factors and criteria that shape and influence our spirituality and to better understand how they play a role in this regard. The spirituality of any people or nation cannot be imagined without its history, unique customs and traditions, life values. In this regard, of course, spiritual heritage, cultural riches, ancient historical monuments serve as one of the most important factors. [7]. Indeed, today's period makes it a necessary task to study in depth and comprehensively the history, national values and cultural heritage of each nation on this basis - to further strengthen the ideas of goodness. As the first President I.A Karimov said: "Inculcating the essence of our traditions, values and heritage in the minds of young people, conveying to young people the integrity of our national and universal values is one of the important factors in the purification of their spirituality" [8]. Therefore, as one of the products of the socioartistic thinking of the people, our traditions and ceremonies, which are passed down from generation to generation and have a socio- aesthetic impact on people, need to be studied in more depth and involve the younger generation.

\section{REFERENCES}

1. Sukhareva O.A.Wedding ceremonies of Tajiks in the city of Samarkand and some other regions of Central Asia.-Soviet Ethnography (hereinafter-SE). Collection of articles, III. M., 1940.-pp.172-176

2. Kislyakov N.A. Essays on the history of family and marriage among the peoples of Central Asia and Kazakhstan. Leningrad., Nauka. 1969.-p.98

3. Emelianenko.T.G. Modern wedding in Karakul: traditions and innovations. Ethnic traditions in culture. Saint Petersburg, 2019.-pp.27-28.

4. Lobacheva N.P. On the formation of a new wedding ceremony among the peoples of Uzbekistan // SE. 1967. No. 2. pp. 15-25.The same text in English. az. in: Central Asian review. 1968. V. 15. No. 4.

5. Sukhareva O. A. Bukhara. XIX - early XX century . (Late Feudal city and its population). M., 1966.- p.64 
FRONTLINE SOCIAL SCIENCES AND HISTORY JOURNAL

(ISSN - 2752-7018)

VOLUME 02 ISSUE 01 Pages: 57-62

SJIF IMPACT FACTOR (2021: 5. 376)

OCLC -1276789625 METADATA IF -7.569

Publisher: Frontline Journals

6. Lobacheva N.P., Tultseva L.A. Traditions in modern Uzbek ritual // SE. 1977. No. 6. pp. 34-44.

7. Karimov I.A. High spirituality is an invincible force. - T .: Spirituality, 2008. - P.30
8. Karimov I.A. The demand of the period of innovative thinking and performance. - $\mathrm{T}$.: Uzbekistan, 1997. - P.245 